\title{
Kültürel Mirasımız ve Arşiv Belgelerimizin Afetler ve KBRN Tehlikelerine Karşı Korunması
}

\begin{abstract}
Yasin ŞEŞEN1
Özet

Dünya; çağlar boyunca çeşitli nedenlerlerle, çeşitli zamanlarda, çeşitli coğrafyalarda çok büyük savașlar ve doğal afetler yaşamıștır. Bu olaylarda milyonlarca insan hayatını kaybetmiș, birçok şehir ve ülke yıkıma uğramıștır. Savașlar ve doğal afetler günümüzde de yaşanmaya devam etmekte ve insanların yaşamını olumsuz etkilemektedir. Devletlerin kendilerini koruyabilmek ve/veya diğer devletleri işgal edebilmek amacıyla geliştirdikleri savaş sanayisi, her geçen gün büyüyen devasa bir canavara dönüşmüştür. Dünyada silahlanma yarışı devam etmekte ve yeni silah teknolojilerine yatırımlar sürmektedir. Savaşlar, insanlığın ortak mirası olan her şeye zarar vermektedir. Zarar gören materyallerin içerisinde 'arşivlerde' bulunmaktadır ve binlerce yıllık arşivlerimiz bu tehlikeli durumdan gelecekte de etkilenebilecek durumdadır. Savaşlar ve 'KBRN' tehditleri insanların sadece can ve mal güvenliğini değil; aynı zamanda 'kültürel, sanatsal ve tarihi kaynaklarını da' yok edebilme riskini taşımaktadır. İlgili çalışma, afetler ve KBRN tehditlerinin arşivlerimiz ile kültürel mirasımıza verebileceği zararları ortaya koymakta, bu zararların nasıl en aza indirilebileceği üzerine görüşler sunmaktadır.
\end{abstract}

Anahtar Kelimeler: Arşivler, Kültürel Miras, KBRN, KBRN Tehditleri, Türkiye.

\section{The Protection of Our Cultural Heritage and Archieve Documents Against Disasters and CBRN Threats}

\begin{abstract}
The world has experienced great wars and natural disasters throughout the ages, with various reasons, at various times, in various geographies. Millions of people have lost their lives in these events, and many cities and countries have been devastated. Wars and natural disasters continue to occur today and affect people negatively. The war industry, developed by the states to protect themselves and/or occupy other states, has become a giant monster that grows day by day. The arms race continues around the world and investments continue in new weapons technologies. Wars damage everything that is the common heritage of humanity. There are 'archives' in the materials that are damaged and our archives for thousands of years can be affected by this dangerous situation in the future. Wars and CBRN its threats are at the risk of destroying not only the safety of life and property of people, but also the 'cultural, artistic and historical resources'. The study presents the evidences that disasters and CBRN threats can
\end{abstract}

\footnotetext{
1 Kütüphaneci, Ankara Üniversitesi Kütüphane ve Dokümantasyon Daire Başkanlı̆̆ı, Ankara. İlgili yazar/Corresponding author: e-posta: ysesen@ankara.edu.tr.
}

Bu makaleye atıf yapmak için- To cite this article Şeșen, Y. (2019). Kültürel Mirasımız ve Arşiv Belgelerimizin Afetler ve KBRN Tehlikelerine Karşı Korunması. Afet ve Risk Dergisi, 2(1), 32-42. 
cause harm to our cultural heritage through our archives, and provide insights on how these losses can be minimized.

Keywords: Archives, Cultural Heritage, CBRN, CBRN Threats, Turkey.

\section{GíRiş}

Afet, belirli bir coğrafya da yaşamını sürdüren insanların hayatlarını olumsuz etkileyen doğal veya insan kaynaklı olaylardır. Her olumsuz olay, afet olarak değerlendirilemez. Uluğ (2016)'ya göre "eğer bir olay, bireylerin ve grupların yașamlarında bir bozulma veya sapma meydana getirmiyorsa bu afet olarak adlandırılamaz. Bir afeti oluşturan iki unsurdan bir tanesi afeti meydana getiren olay; diğeri de olayın meydana geldiği toplum yapısıdır. Bu bakımdan, bir toplum için afet olarak sayılan bir olay, başka bir toplum için afet sayılmayabilir". Varol ve Gültekin (2016)'ya göre "afet, ekonomik ve sosyal kayılara neden olan, sosyal hayatı kesintiye uğratan ve ani olarak gelişen olaylar olarak tanımlanır". Afetlerin çoğunluğu doğal kökenlidir; bazı durumlarda insan faktörü de söz konusudur. Afetler, can ve mal kayıplarına yol açarak günlük yaşamın olağan seyrini önemli ölçüde etkileyebilmektedirler. Türkiye'de afetler sonucu oluşan kayıplar, o güne kadar uygulanan kriz yönetimi anlayışının değişmesi gerektiğini göstermiştir. Özellikle 1999 Marmara ve Düzce Depremlerinde, afet kurumlarından önemli birisi olan Kızılay teçhizat ve afet yönetimi açısından yetersiz kalmıştır.

Afetlerden korunmak ve/veya afetten etkilenen bölgeleri tekrardan aktif duruma getirebilmek için 'afet yönetimi politikaları' inşa edilmektedir. Afet yönetimi politikalarının inşa edilmesinin en önemli amacı olarak Akay (2007) "doğal kaynakların en rasyonel şekilde, yani korumakullanım dengesi sağlanarak oluşturulması ve yaşam kalitesi yüksek, afetlere dayanıklı, sağlıklı kentlerin geliștirilmesidir" demektedir. Erkal ve Değerliyurt (2009)'ya göre afet yönetimi, "birçok kurum ve kuruluşun koordineli bir biçimde görev almasını gerektiren ve insan hakları için fiziksel, ekonomik ve sosyal kayıplar meydana getiren durumların düzeltilmesi için yoğun çalıșılmasını içeren planlı ve programlı sistemler bütünüdür".

Varol ve Kaya'ya (2018) göre "afet sürecinin bir önceki aşamasında yapılan faaliyetlerin başarısı bir sonraki aşamasında yapılacak faaliyetlerin başarısını etkilemektedir. Bu süreçler iç içe geçmiş faaliyetlerdir ve bir döngü oluştururlar". Afet yönetimi uygulamalarına eğitim/öğretim yaşamının her aşamasında yer verilmelidir. "Afet risklerini azaltma ve hazırlık stratejileri ile ilgili eğitimlerin müfredat programlarına dâhil edilmesi, afetlerin olumsuz sonuçlarının azaltılmasına yönelik pozitif bir yaklaşım olacaktır”(Dökmeci ve Merinç, 2018).

Afetlerin oluşumunu ve şiddetini değiștiren çeşitli faktörler vardır. Bu faktörler, afetlerden etkilenen bölgelerde hayatını kaybeden ve/veya yaralanan insan sayısını da etkilemektedir. $\mathrm{Bu}$ faktörlerin biraraya gelmesiyle, afetin şiddeti ve etkisini ortaya koyan istatistiki bilgiler elde edilebilir. İstatistiki bilgiler gelecekte meydana gelecek olan afetlere hazırlık yapılabilmesi açısından önemli verilerdir.

Afetlerin oluşumu temelde iki faktöre dayanır. Oluşumlarına göre afetler; insan faktörü olmayan 'doğal afetler'; tamamen insan faktörüyle meydana gelen 'insan kaynaklı afetlerdir'.

'Doğal afetler' kendi içerisinde dört grupta incelenir:

- Jeolojik kökenli afetler,

- Klimatik afetler,

- Hidrografik afetler, 
- Biyolojik afetler.

İnsan kaynaklı afetler kendi içerisinde iki grupta incelenir:

- Sosyal afetler,

- Teknolojik afetler.

\subsection{Insan Kaynaklı Afetler}

İnsan faktörüne bağlı olarak ortaya çıkan insan kaynaklı afetler; nükleer, biyolojik, kimyasal kazalar vb. birçok nedenden ortaya çıkabilmektedirler. İnsanın yaşadı̆̆ı her alanda, insan kaynaklı afet görülme riski de yüksektir.

KBRN olarak bilinen kimyasal, biyolojik, radyasyon ve nükleer ajanlar da, insan kaynaklı afet kategorisine girmektedir. "KBRN, 1990 sonrası dünyanın kozmik ortamında artan küresel terörizm ve terör gruplarının stratejilerinde kitlesel zararın önemli bir yer tutmasıyla, terörizm aracı olarak daha fazla gündeme gelmeye başlamıştır" (Sidell, 1997). "Bununla birlikte, terör örgütleri, büyük ölçekli korku, panik, sosyal ve ekonomik bozulma yaratmak, hükümetlerin savunma harcamalarını arttırmak içinde KBRN ajanlarını kullanabilirler" (Ruff, 2006). KBRN harp maddeleri, geçmişte birçok savaşta kullanılmıştır ve gelişen teknolojiyle birlikte bu riskin her geçen gün daha büyük bir tehdit olduğu görülmektedir. KBRN ajanları biraz daha ayrıntılı olarak şu şekilde incelenebilir:

Kimyasal silahlar; "kişileri öldürerek veya yaralayarak etkisiz hale getirmek, besin kaynaklarını kirletip, ekonomik önemi olan hedefleri işlemez hale getirmek, gerek askeri gerekse sivil personeli koruyucu ekipman kullanmak zorunda bırakarak hareketlerini kısitlamak, toplumda teröre ve paniğe sebep olmak amacıyla kullanılan toksisitesi yüksek kimyasal maddelerdir" (Kenar, 2018). Biyolojik silahlar; canlı kitleleri öldürme amacıyla kullanılır. Radyoaktif/Nükleer Silahlar; maddeyi iyonize edici etkisinden dolayı canlı kitleleri öldürme, amacıyla kullanılan radyoaktif maddelerdir.

'KBRN tehdidi' insanların sadece can ve mal güvenliğini değil, aynı zamanda kültürel, sanatsal ve tarihi kaynaklarını da yok edebilme riskini taşımaktadır. İlerleyen bölümlerde kültürel mirasımız ve sanat tarihimiz hakkında bilgiler verilmiş; 'KBRN saldırılarından' eserlerimiz ve belgelerimizin nasıl korunabileceği üzerinde durulmuştur.

\section{TÜRK TARİHINDE KÜLTÜREL MİRAS KAVRAMI VE KÜLTÜR VARLIKLARI}

Türk tarihi boyunca kurulan; çeşitli soy, aile, beylik, devlet v.b. kurumlarda üretilen tüm eserler tarihimizi yansıtması açısından oldukça önemlidir. Özellikle tek bir nüsha ve/veya nadir olarak bulunabilecek bir eserin saklanarak, gelecek kuşaklara aktarılması gerekmektedir. Gelecek kuşaklara aktarım, kültürel mirasın kavranması ve korunması ile mümkün olur. Toplumun kültürel anlamda gelişmesi ve içerisinde bulunduğu çağın gerisinde kalmaması açısından bu nadir eserlere verimli şekilde ulaşım sağlanabilmelidir. "Topluma hizmet etmek ve vatandaşların gereksinim duyduğu bilgiye yeterli, güncel ve zamanında erişmesini sağlamak amacıyla bilgi yayımının gerçekleştirilmesi en temel hedeftir. Bilgi yayımını gerçekleştiren en önemli kurumlar arşivler ve kütüphanelerdir" (Şeşen ve Gürbüz, 2018). Arşivler ve kütüphaneler aynı zamanda kültürel mirasın korunmasından da dolaylı yoldan sorumludurlar.

Kültürel miras veya kültür mirası; "bir toplum, topluluk ya da kitlenin hali hazırda muhafaza ettiği, kendinden önceki kuşaklar (ataları) tarafından oluşturulmuş somut/maddi veya somut olmayan varlık ve olguların tümüdür. Kültürel miras: Bina, anıt, kitap, sanat eserleri veya el işleri gibi somut maddelerdir" (Url 1). 


\section{YAZMA ESER VE NADİR ESERLERIMIIZİN KORUNMASI}

Bölüm; üç (3) başlıkta incelenecektir, bu başlıklar şunlardır: El yazmaları/Yazma eserler, Nadir eserler, Yazma ve Nadir eserlerimizin korunmasıdır.

\subsection{El Yazmaları / Yazma Eserler}

El yazmaları, genellikle kâğıt veya parşömen üzerine yazarın kendi el yazısıyla yazılmış orijinal dokümanlardır. “Türkiye'de, resmî kütüphanelerdeki yazmaların sayısı 500.000'dir ve \%80'i Kültür ve Turizm Bakanlığı'na bağlı kütüphanelerdedir. Kütüphanelerdekilerin dıșında, özel kurum ve şahısların elindeki tahmini 100.000 eserle birlikte bu sayı 600.000'e ulaşmaktadır" (Duman, 1997).

\section{2. Nadir Eserler}

Nuhoğlu 2014 yılında ele aldığı çalışmasında nadir eserleri, "benzeri bulunmayan, benzerlerinden farklı olan, ihtiyaç duyulduğunda elde edilmesi çok zor olan veya mümkün olmayan eserlerdir" olarak tanımlamaktadır. Nadir eserler, hem sayıları hem de maddi değerleri açısından eşsiz eserlerdir.

\section{3. Yazma ve Nadir Eserlerimizin Korunması}

Yazma ve nadir eserlerin korunması önemlidir. "Yazma ve nadir eserlerin, ısı, nem, ışık, zararlı haşereler, yangın, su baskını, deprem ve sabotaj ile hırsızlık v.b. çevreden gelebilecek zararlardan korunması gerekmektedir" (Bayraktar, 1990). Bu tehditlere ilave olarak, yazma ve nadir eserlerimizin KBRN tehditlerinden korunması için ayrıca ilave tedbirler alınmalıdır.

Eserlerin korunmasında kullanılan yöntemlerden birisi dijitalleştirmedir (sayısallaştırma)'. Sayısallaştırmanın amacı: Bilgi, kültür ve sanat değeri olan materyalin (kültürel miras) korunması, kayıt altına alma, bilginin geniş kesimlere yayılması, uzun vadeli olarak yedeklenme, yıpranma, çalınma gibi riskleri ortadan kaldırmaya yöneliktir.

\section{DÜNYADA VE TÜRKIYE'DE BELGE KORUNMASI VE DİJITTALLEŞTİRILMESİ ÇALIŞMALARI}

Dünyanın en büyük kütüphanelerinden birisi 'Amerikan Kongre Kütüphanesidir'. A.B.D.'nin başkenti Washington D.C.'de üç farklı binada yer alır. "Amerikan Kongre Kütüphanesi, 1815 yılında Thomas Jefferson, kütüphanesinde yer alan tüm kitapları (6.487 adet) bu kütüphaneye bağışlamış ve kütüphane zamanla büyümüştür. Kütüphane, zaman içinde eğitim ve akademik amaçlarla tarihsel ve kültürel materyalleri korumayı amaç edinmiştir” (Hubbell, 2009). Amerikan Kongre Kütüphanesinde gelecek kuşaklara kazandırılmak için birçok eser korumaya alınır. Örneğin, Amerikan Heavy Metal grubu olan Metallica'nın 1986 yılında çıkan ve metal tarihinin en iyi albümlerinden biri olarak kabul edilen üçüncü albümü 'Master of Puppets', Kongre Kütüphanesi'nin Milli Kayıt Sicili tarafından gelecek nesillere aktarılması adına korumaya alınan albümleri arasına seçilmiştir. Metallica'nın (Url 2) yorumu șu șekildedir; "2002 yılında başlatılan ve bu yıl 450 olan seçki içerisinde yer almaktan ve John Coltrane, Merle Haggard, Santana ve George Carlin gibi devler arasına katılmaktan dolayı son derece gururlu ve müteşekkir durumdayız. $\mathrm{Bu}$ albümün bu şekilde onurlandırılması bizim için gerçekten muhteşem bir duygudur".

Amerikan Kongre Kütüphanesinde ki arşivleme ve eser koruma sisteminde de gördüğümüz gibi, Amerikan Ülke Yönetim Sistemi gelecek kuşaklara ulaşabilmek için her daim çaba göstermektedir. Bunun getirisi olarakta, ülkesinde ve dünyada olan tüm önemli olayları sürekli kayıt etmekte, hayatın her alanından seçtiği türlü eserleri de sürekli saklamaktadır. A.B.D.; 1776 yılındaki kuruluşundan itibaren geçen süre boyunca dünyadaki birçok ülkenin ulaşamayacağ bir tarihi geçmişi elinde tutmuştur ve gelecekte de tutmaya devam etmek için mücadele etmektedir. 
Kültürel Mirasımız ve Arsiv Belgelerimizin Afetler ve KBRN Tehlikelerine Karsı Korunması

Dünyada bașta Amerikan Kongre Kütüphanesinin uyguladı̆̆ı ve zaman içerisinde Türkiye'nin de benimsediği çeşitli eser koruma yöntemleri vardır. Osmanlı arşiv teşkilatına 'Hazine-i Evrak' denilir. Son yıllarda el yazmalarının onarım ve bakımları için Kütüphaneler Genel Müdürlüğü tarafından İstanbul'da bulunan Ziver Bey Konağı'nda 'İstanbul Yazma ve Nadir Eserler Patoloji ve Restorasyon Araştırma Merkezi’ açılmıştır. Zamanla arşivleme ve belgelerin korunması işlemi, 'Konservasyon' ve ‘Konsültasyon’ olmak üzere iki aşamada ele alınmaya başlanmıştır.

\subsection{Belgelerin Korunma Yöntemleri}

Konservasyon ișlemi, belge korumanın önemli bir aşamasıdır. "Konservasyon; arşiv belgelerinin fizikî, kimyevî, biyolojik, mekanik ve bunlar dışında kalan çeşitli tahrip unsurlarıyla bozulup ana özelliklerini kaybetmesini önlemek ve belli şartlarda korunmasını sağlamak amacıyla yapılan çalışmalardır. Konsültasyon; arşiv belgesi ve elyazması malzemeyi belli mevzuat çerçevesinde hakikî ve hükmî şahısların, devletin ilim ve kültürünün hizmetinde istifadeye sunulması işlemleridir" (Url 3).

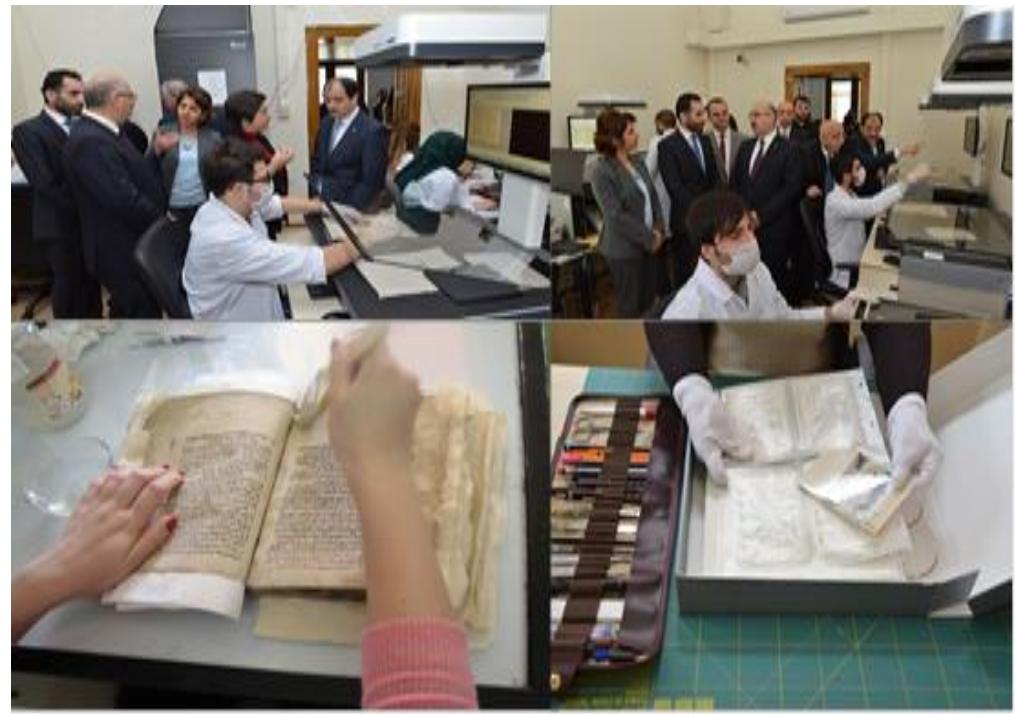

Şekil 1. Konservasyon - Konsültasyon Merkezleri (Url 3)

\subsection{Belgelerin Dijitalleștirmesi}

Dijitalleştirme genel olarak elektronik sistemlerce algılanamayan yapılandırılmamış formdaki bilginin, elektronik ortamca algılanabilecek yapılandırılmış forma çevrilmesi uygulamalarını tanımlamak için kullanılmaktadır. "Dijitalleștirme uygulamalarının önemi bir yönünü dijital koruma olușturmaktadır. Elektronik ortamlarda üretilen belgeler yanında basılı ortamda olup elektronik sistemlerde de görünürlükleri sağlanan belgeler dijital korumanın kapsamını daha da genişlemektedir" (Rieger, 2008). Dijitalleştirme sayesinde belgenin orijinalinin yıpranması önlenmektedir. Ayrıca belgelere erişimde büyük kolaylık sağlamaktadır. Ulusal ve kültürel mirasın korunmasını, saklanmasını ve bu belgelerin insanlarla kolayca buluşmasını sağlar. Bunun yanında belgelerin dijital ortamda olması yangın, sel, deprem vb. afetlere karşı da belgelerin daha dayanıklı olmasını sağlamaktadır. Kâğıt ve depolama alanı gibi maliyeti fazla olan şeylerden tasarruf edilerek maliyet azalmaktadır.

Belgelerin dijitalleștirilmesinde kullanılan en önemli faktör standartlaşmadır. Belgelerin standart bir düzen içerisinde tasnif edilmesi ve dijitalleştirilmesi önemlidir. "Dijitalleştirme, henüz yeni ve teknolojinin de etkisiyle sürekli değişen dinamik bir konudur. Ayrıca, kurumların kendi ihtiyaçları doğrultusunda oluşturdukları bir takım dijitalleştirme standartları da vardır. $\mathrm{Bu}$ yüzden bu konudaki standartlar, standarttan çok bir öneri niteliği taşımaktadır"(Kalkan, 2016). 
Belgelerin dijitalleştirilmesi kapsamında kullanılan başlıca standartlar: "ISO/TR 13028: 2010: Dijitalleştirilmiş kayıtların güvenilirliği erișimi, alıkoyulması ve dijital olmayan kayıtların imhası ilgili gerekliliklerin yer aldığı standarttır. ISO/TR 19005: Kısaca PDF/A olarak da bilinen ISO/TR 19005, Portable Document Format (PDF)'in belgelerin uzun süreli muhafazası için kullanımını ele alan standarttır" (Angeles, 2009).

Belgelerin korunması ve bilginin sayısallaştırılmasının temel amaçları arasında, bilgi toplumuna geçiş ve sürekli öğrenme felsefesinin oturtulması bulunmaktadır. Böylece, bilgi ve belgelerin korunarak gelecek kuşaklara aktarılması da kolaylaşacaktır. "Bilgi toplumunda rolleri değişen meslek grupları, bilgisayar programcıları, çözümleyiciler, yayıncılar, kütüphaneciler, halkla ilişkiler uzmanları, sosyal bilimciler ve bürokratlardır. Bu meslek gruplarının ortak özellikleri bilgi üretmeleri, düzenlemeleri ve bilginin yayımını gerçekleştirmeleridir" (Anameriç ve Rukancl, 2004).

\section{TÜRKIYY'DE BELGE DİJITTALLEŞTİRILMESİ YAPILAN KURUMLAR VE İLGİLİ MEVZUAT}

Türkiye'de dijitalleştirme çalışmalarına değinilince en başta; Ankara Üniversitesi E-Beyas (Elektronik Belge Yönetimi ve Arşiv Sistemi) sisteminin tamamen oturtulması ve diğer kurumlara transferi, Dışişleri Bakanlığı Diplomatik Arşivi, Milli Kütüphane, Ankara Üniversitesi Siyasal Bilgiler Fakültesi Dergi Arşivi Dijitalleştirme Çalışmaları v.b. dijitalleştirme çalışmaları akla gelmektedir. Bu projeler zaman içerisinde hayata geçirilmiştir ve projelerde tespit edilen eksikliklerde sürekli düzeltilmektedir.

İstanbul'da "Milli Arşiv Sitesi" inşa edilmiştir. Cendere vadisinde inşa edilen binanın deprem ve sel bașta olmak üzere her türlü doğal afete karșı dayanıklı olarak tasarlandığı bilinmektedir. Dünyanın en büyük tarih arşivi olacak binada, 370 bin civarında defter, 100 milyon civarında da belge bulunması planlanmaktadır. Şekil 2'de, “Milli Arşiv Sitesi”nin (Url 4) bir resmi verilmiştir.

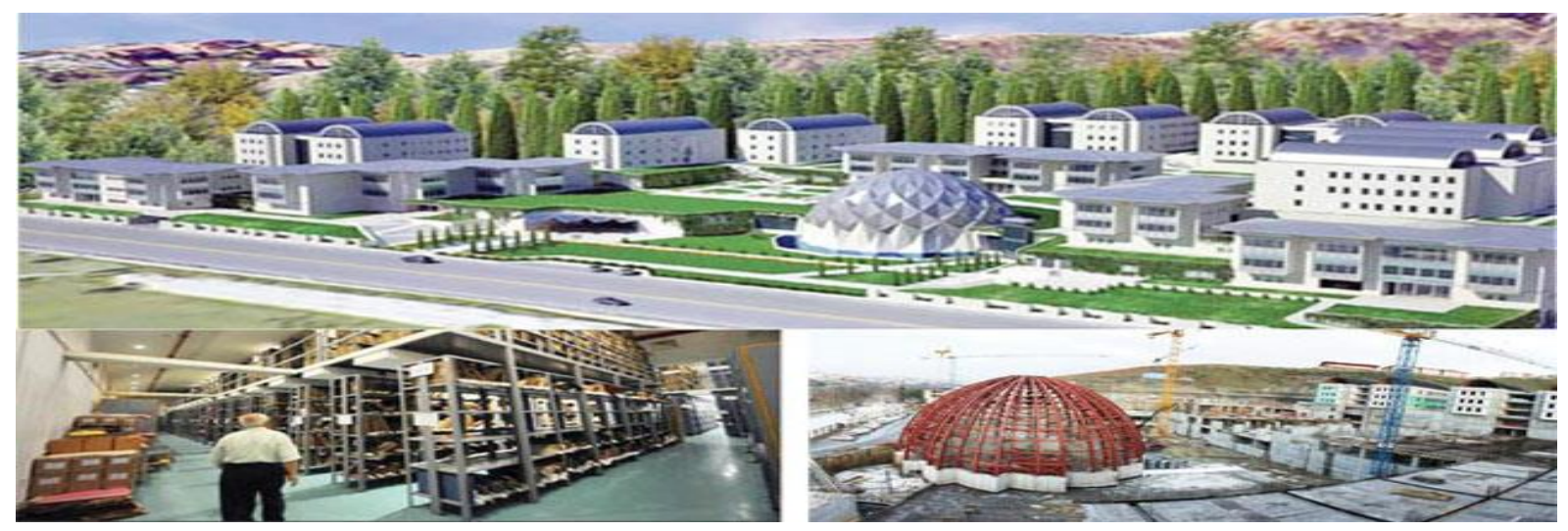

Şekil 2. Milli Arşiv Sitesi (Url 4).

Dijitalleştirme ile ilgili mevzuatın pratikteki uygulaması; 2006 yılından itibaren e-devlet üzerinden erişilebilen "Tapu Kadastro Bilgileri" ile 2018 yılında e-devlet üzerinden verilmeye başlanılan "Alt-Üst Soy Bilgisi Sorgulama” hizmetidir.

\section{KBRN SALDIRILARINDAN KÜLTÜREL MİRAS VE ARŞIV BELGELERININ KORUNMA YÖNTEMLERİ}

Dünya gelişmektedir ve sürekli olarak savaşlar ve afetler sürmektedir. Savaşlar ve afetlerden dolayı kültürel bellek kurumları (kütüphaneler, arşivler, müzeler vb.) maalesef tehlike altındadır. Yalnızca birkaç ülke değil, 'Global Köy' ve 'Evrensel İnsan' her gün kaybetmektedir. Yangınlar, çevre felaketleri ve savaşlarda gelişmiş silahların kullanılması birçok eserin kaybına 
Kültürel Mirasımız ve Arsiv Belgelerimizin Afetler ve KBRN Tehlikelerine Karsı Korunması sebep olmaktadır. Bu durumun en yakın örneği Suriye kültürel mirasının savaş nedeniyle tahrip edilmesi, yağmalanması ve yıkılmasıdır. Kültürel mirasa tüm uluslar sahip çıkmalıdır, çünkü kültürel miras tüm insanlığa aittir.

Afetlerden korunabilmek için 'afet zarar azaltma ve iyileştirme planları' çizilmeli ve uygulanmalıdır. Afet zarar azaltma ve iyileștirme planının amacl, kurumların afetten önce yapması gereken işlemleri hayata geçirmeleri ve verimli şekilde afete hazır durumda beklemelerinin sağlanmasıdır.

2017 yılında 'Afet Zarar Azaltma ve İyileștirme Ortak Plan Grubu' (Şekil 3) oluşturulmuștur.

Ülkenin afet politikası çizilip, afet zarar azaltma, iyileştirme ve risk değerlendirme çalışmaları yapıldıktan sonra; elde edilen verilerin saklandığı ve gelecekte değerlendirildiği 'Ulusal Afet Veri Tabanı' inşa edilmektedir. "Veriyi doğru toplamak kadar bu verileri aynı formatta hazırlamak ve belli bir standarda göre tasnif etmek ve gerektiğinde kolayca ulaşabilmek de çok önemlidir. $\mathrm{Bu}$ bakımdan afet öncesi çalışmalar için doğru bir veritabanı modeli seçilmelidir. Türkiye'de İstanbul Teknik Üniversitesi tarafından yapılan bir çalışmanın sonucunda Türkiye Afet Bilgi Standardı (TABİS) geliştirilmiştir. Burada amaç her kurum ve bölgenin bu detayda mümkün olduğunca bilgi toplaması ve saklamasıdır" (Kadığlu, 2011).

Gelişmiş ülkelerdeki kütüphane ve arşiv yapılarının korunmasında 'İş Sağlığı ve Güvenliği birimlerini' görev yaparlar. Bu birimler arşivlere yönelik meydana gelebilecek 'acil durum/afet ve KBRN saldırıları vb.' karşı tedbirler almaktadırlar. Afetlerle ilgili kurumlar koruma ve geliştirme konusunda olmak üzere, geniş ölçekli ve katılımlı işbirliği çalışmalarını başlatmışlardır. Kuzucuoğlu(2014a) "Afet Yönetim Planlaması kapsamında; 'Acil Durum Planları, Kurtarma ve Tahliye Planları, Yangın Planları, İlk Yardım Planları vb.' içermektedir. Bu planlarda tüm çalışanların görev ve sorumlulukları tanımlanmakta, öncelikle can güvenliği olmak üzere arşivlerin kurtarılması amaçlanmaktadır. Bu konularla ilgili periyodik eğitim çalışmaları devam etmektedir. Ülkemizde de Avrupa Birliği Uyum Yasaları çerçevesinde sürekli güncellenen mevzuatlar (6331 sayılı İş Sağlığı ve Güvenliği Kanunu ve ilgili yönetmelikler) risk değerlendirilmesi ve acil durum planlarının hazırlanmasını zorunlu hale getirmiștir" demektedir.

Arşiv binalarında afetlerden korunabilmek amacıyla öncelikle risk değerlendirme çalışmaları yapılmalıdır. Kuzucuoğlu(2014b) "Risk değerlendirilmesi yapılırken, bu tehlikelerin kaynakları, bunlardan kimlerin zarar görebileceği ve sonuçta oluşabilecek çoklu etkiler öngörülmelidir. Bu binalarda sadece afet durumuna değil, olası bir acil duruma göre de planlama yapılmalıdır. Acil durum tahliye planlarının hazırlanması işlemleri yapılmalıdır" demektedir. 


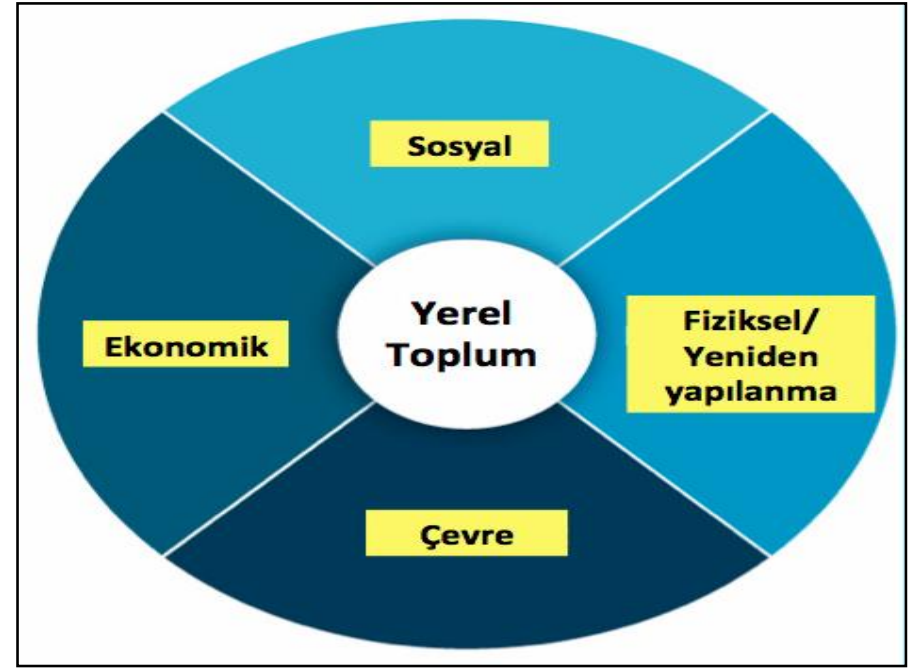

Şekil 3. Afet Zarar Azaltma ve İyileștirme Ortak Plan Grubu (Url 5)

Afet öncesinde alınan önlemlerin standartlara uygun olması ve mümkünse de sürekli kontrol edilerek ileri seviyeye ulaștırılabilmesi, ülkede bulunan her türlü eserin korunabilmesini sağlayacaktır. 'Arşiv binaları güçlü bir yapı üzerine kurulursa', 'binaların tahliye planları zamanında gerçekleștirilebilirse' ve 'yetişmiş uzman personelin her türlü güvenliği sağlanabilirse'; afet durumunda ve/veya afetten sonra da kısa bir süre içerisinde eserlerin tahliye işlemleri gerçekleștirilebilir. Afetten önce alarm sisteminin kurulabilmesi önemlidir, çünkü daha olay cereyan etmeden olabileceklere karşı önlem alınabilir. Bu konuda arşivin korunabilmesi için, gelişmiş elektronik bir koruma sistemi gerekmektedir. Bunun yanında, afet sonrasında eserlerin niteliğinin korunabilmesi amacıyla, bir süre geçici depolarda muhafaza edilebilmeleri, daha sonra ise kalıcı mekânlara transfer edilebilmeleri sağlanmalıdır. 'KBRN saldırıları' gibi aniden ve çok ölümcül șekilde meydana gelen afetler durumunda, eserlerin korunması ve aynı zamanda kimyasal maddelerle temas eden materyallerin dezenfekte edilebilmeleri amacıyla uzman personel yetiștirilmelidir. Bu konuda üniversitelerin 'Bilgi ve Belge Yönetimi, Afet Yönetimi, Mühendislik Bölümleri ve Tıbbi Dokümantasyon Bölümlerine' büyük görevler düşmektedir ve bu bölümlerde ilgili uzmanlık konularında lisansüstü dersler verilmesi önemlidir.

Her koşulda afetten önce alınması gereken güvenlik önlemleri oldukça önemlidir. Bu konuyu Kadığlu (2017) "Afet risk yönetiminde yapılacak olan sistematik çalışmalar ile afetlerin neden olabileceği olumsuz etkilerini en baştan önlemek, afet sonrası iyileştirme çalışmalarını önemli ölçüde azaltmak afet yönetimin temel hedefidir. Çünkü iyileştirme çalışmaları ne kadar başarılı olursa olsun asla afette oluşacak olan can ve mal kayıplarını yerine koyamaz" şeklinde ifade etmektedir.

\section{SONUÇ VE ÖNERILER}

Türkiye'de son 50 yıldır yapı bloğunun değișmesi, beraberinde afete karşı yetersiz binaları ortaya çıkarmıştır. Denetleme eksikliği, rüşvet, arazi afları vb. nedenlerden dolayı mevzuatlar uygulanmamıştır. Türkiye afetlerde büyük darbeler almış bir devlettir. 1999 Marmara ve Düzce depremleri ile 2011 Van depreminden sonra ülkenin afetten zarar gören yerleri tekrar kalkındırabilmesi için harcadığı paralarının miktarının aşırı yüksekliği, 'afetler meydana gelmeden önce önlem alınmasının gerekliliğini' göstermiștir. 2012 yılında 364 doğal afet, 188 teknolojik afet meydana gelmiştir ve 157,5 milyar TL harcanmıştır. Bugüne kadarki deneyimler, 
Kültürel Mirasımız ve Arsiv Belgelerimizin Afetler ve KBRN Tehlikelerine Karsı Korunması ülkemizin olası afetlerin birçoğuna hazır olmadığı açıkça göstermektedir. Afet yönetimi birçok konuda sadece mevzuat üzerinde kalmaktadır. Sadece deprem konusunda DASK (Doğal Afet Sigortaları Kurumu)'ın kurulumu ile birlikte 'zorunlu deprem sigortası poliçeleri yaptırılması' konusunda bir nokta ilerleme gösterilmiştir. Türkiye'nin hızlanması gereken birçok konu vardır. Kentsel dönüşüm, planlı şehircilik uygulamaları hızlandırılarak bütün ülke çapına yayılmalıdır. Afet'e hazır olmak için yapılması gereken devlet politikaları ve halkın üzerine düşen görevler şunlardır:

7269 sayılı Afetler Yasası, risk yönetimi ilkelerine uygun olarak yenilenmelidir.

> 3194 sayılı İmar Yasası'nın yapısı günün şartlarına uymalıdır.

$>$ Risk odaklı süreçler güncellenmelidir.

$>$ Risk azaltma konusunda çeşitli kurslar her kurum için ayrı ve özel olarak açılmalı ve eğitimlere kalıcı olacak şekilde devam edilmelidir.

> Türkiye Afet Risk Azaltma Ulusal Planı (TARAP) konusunda dikkat edilecek hususlar vardır. Mevzuat yine gözden geçirilmelidir. Afet risk azaltma kılavuzları standartlaştırılmalıdır.

> 'Türkiye Afet Bakanlığı' kurulmalıdır. Afetlerden sorumlu olan tüm devlet kurumları ve sivil toplum kuruluşları; faaliyetlerini kurulacak bu bakanlı̆̆ın denetimi altında sürdürmelidir. Tüm bu kurum ve kuruluşlar olası bir afetten sonra koordineli bir şekilde çalışmalıdır. KBRN kaynaklı afetlerden sonra ilgili yönetmeliğin görev ve sorumluluk verdiği kurum ve kuruluşlar da benzer çalışmalar yürütmelidir.

Afet yönetiminde ileri ülkelerdeki afetlerle mücadele modelleri Türkiye koşullarına uyarlanmalıdır.

> Televizyon yayınlarında afet potansiyelleri ve afet yönetimine ilişkin kamu spotları ile kısa süreli belgesellere yer verilmelidir. Bu konuya ilişkin faaliyetler ise Radyo Televizyon Üst Kurulu tarafından takip edilmelidir.

Sonuç olarak; kültürel miras ile arşiv belgelerinin afetler ve KBRN tehditlerine karşı korunması amacıyla; tüm ülke kuruluşları üzerlerine düşen görevleri yerine getirmelidir.

\section{KAYNAKLAR}

Akay, A. (2007). Çevre Düzeni Planları ve Yetki Sorunları. Amme İdaresi Dergisi, 40 (3), 113-148.

Anameriç, H. ve Rukancı, F. (2004). Bilgi toplumu ve toplumun bilgilenmesinde kütüphanelerin rolü. Sacit Arslantekin ve Fahrettin Özdemirci (Yay. Haz.). Kütüphaneciliğin Destanı Uluslararası Sempozyumu bildiriler: Saga of Librarianship International Symposium proceedings içinde (s. 330-338). Ankara: Ankara Üniversitesi DTCF Bilgi ve Belge Yönetimi Bölümü.

Angeles, N. C. (2009). Standards and Procedure in Digitization and Digital Preservation.

Bayraktar, N. (1990). Yazma kitapların güvenliği. (Hazl.) Doğan Atılgan ve Fahrettin Özdemirci. Türk Kütüphaneciler Derneği 40. Yıl Kütüphanecilik Kurultayı 30 Kasım-1 Aralık 1989 Bildiriler içinde. Ankara: Türk Kütüphaneciler Derneği.

Dökmeci, A. H. ve Merinç, F. (2018). Namık Kemal Üniversitesi Öğrencilerinin Temel Afet Farkındalığının Değerlendirilmesi. Afet ve Risk Dergisi, 1(2), 106-113. 
Duman, H. (1990). El yazmaları dünyasında Türkiye’nin yeri. Ankara: Kültür Bakanlı̆̆ı.

Erkal, T. ve Değerliyurt, M. (2009). Türkiye'de afet yönetimi. Doğu Coğrafya Dergisi, 14 (22), 147-164.

Erkan, A. (2010). Afet yönetiminde risk azaltma ve Türkiye'de yaşanan sorunlar. Ankara: T.C. Başbakanlık Devlet Planlama Teşkilatı.

Hubbell, F. (2009). American memory a primary source, Library and Information Science Community.

Kadıoğlu, M. (2011). Afet Yönetimi Beklenilmeyeni Beklemek, En Kötüsünü Yönetmek. T.C. Marmara Belediyeler Birliği, 65.

Kadıoğlu, M. (2017). Afetlerde Zarar Azaltma ve İyileştirme Planlaması. TMMOB Jeoloji Mühendisleri Odası İstanbul Şubesi Kent ve Jeoloji Sempozyumu, 12-14 Mayıs 2017 içinde. İstanbul: Kadir Has Üniversitesi Cibali Kampüsü.

Kalkan, F. (2016). Belgelerin sayısal ortama aktarılması ve dijital depolama; uygulamalar, standartlar ve sorunlar: Türkiye'de konuyla ilgili çalışan şirketler ve uygulamaları ile kurumsal uygulama örnekleri. Ankara: Hacettepe Üniversitesi Ders Slâytları.

Kenar, L. (2018). KBRN Silahları Hakkında Bilgiler. Ankara: T.O.D.A.I.E. KBRN ve Risk Yönetimi Ders Sunumları.

Kuzucuoğlu, A. H. (2014a). Arşiv binalarında risklere yönelik koruma çalışmaları: İstanbul Büyükșehir Belediyesi Arşivleri örneği. Arşiv Dünyası, Sayı 16-17 (Kış-Yaz), s. 6-15.

Kuzucuoğlu, A. H. (2014b). Kütüphanelerde yapısal olmayan malzeme kaynaklı riskler. Bilgi ve Belge Araştırmaları Dergisi, 2, 21-38.

Nuhoğlu, H. (2004). Nadir eserler. Haz. Ümit Konya. 40. Kütüphane Haftası Bildirileri (29 Mart - 4 Nisan 2004, İstanbul) içinde. İstanbul: Türk Kütüphaneciler Derneği İstanbul Şubesi, 12-20.

Rieger, O. Y. (2008). Preservation in the age of large-scale digitization. Washington: Council on Library and Information Resources.

Ruff, T. (2006). Nuclear Terrorism: Energy Science.

Sidell, Frederick R., Takafuji, Ernest T., Franz, David R. (1997). Field Management of Chemical Casualties. Washington: Medical Aspects of Chemical And Biological Warfare.

Şeşen, Y. ve Gürbüz, K. (2018). Belediyelerin kütüphanecilik faaliyetlerinin stratejik planlar üzerinden analizi. Avrasya Sosyal ve Ekonomi Araştırmaları Dergisi (ASEAD), 5(7), 143-150.

Türkiye Afet Yönetimi Strateji Belgesi, (2015). Afet Yönetimi Strateji Belgesi. (29.5.2009 tarihli 5902 sayılı Afet ve Acil Durum Yönetimi Başkanlığının Teşkilat ve Görevleri Hakkında Kanun ile Onuncu Kalkınma Planı 2014-2018 doğrultusunda hazırlanmıştır).

Uluğ, A. (2009). Nasıl Bir Afet Yönetimi?. TMMOB 1. İzmir Kent Sempozyumu Bildirileri içinde (s. 1-18) İzmir: İzmir İl Koordinasyon Kurulu.

Url 1, https://acikders.ankara.edu.tr/pluginfile.php/6887/mod resource/content/2/Konu\%201.pdf. (Son erişim: 05.01.2019)

Url 2, http://www.pasifagresif.com/2016/03/master-of-puppets-abd-kongre-kutuphanesi-kapsaminaalindi/ (Son erişim: 05.01.2019) 
Kültürel Mirasımız ve Arsiv Belgelerimizin Afetler ve KBRN Tehlikelerine Karsı Korunması

Url 3, https://www.devletarsivleri.gov.tr/varliklar/dosyalar/eskisiteden/yayinlar/cumhuriyet-arsiviyayinlar/AR\%C5\%9E\%C4\%B0V\%20MALZEMELER\%C4\%B0N\%C4\%B0N\%20KORUNMASI\%20VE\%20R ESTORASYONU.pdf. (Son erişim: 08.02.2019)

Url 4, http://www.bbyhaber.com/bby/2013/03/04/600-yillik-tarihi-hafiza-guvende-mi. (Son erişim: 06.04.2019)

Url 5, https://www.afad.gov.tr/upload/Node/3479/xfiles/afet_sonrasi_iyilestirme_calismalari-1.pdf. (Son erişim: 04.04.2019).

Varol, N. ve Gültekin, T. (2016). Afet Antropolojisi. Elektronik Sosyal Bilimler Dergisi, 15(59), 1431-1436. (DOI:10.17755/esosder.89650)

Varol, N. ve Kaya, Ç. M. (2018). Afet Risk Yönetiminde Transdisipliner Yaklaşım. Afet ve Risk Dergisi, 1(1), $1-8$. 